\author{
Halina Pelcowa \\ Uniwersytet Marii Curie-Skłodowskiej w Lublinie \\ ORCID: 0000-0002-1380-4943 \\ halina.pelc@poczta.umcs.lublin.pl, hapelc@poczta.onet.pl
}

\title{
Hasło w słowniku gwarowym - problem metodologiczny współczesnej dialektologii
}

\begin{abstract}
Abstrakt: Przedmiotem rozważań są problemy metodologiczne związane z wartością naukową i poznawczą hasła słownikowego, rozpatrywane w aspekcie praktycznej użyteczności słowników gwarowych regionalnych i lokalnych oraz ich przydatności w dialogu pokoleń i promocji regionu. Istotą hasła słownikowego jest zarówno liczba i układ poszczególnych jego segmentów składowych, ich reprezentatywność i możliwość oddziaływania, jak i włączenie do słownika mapy i ilustracji, zarezerwowanych jeszcze do niedawna dla innych publikacji. Mapa i ilustracja powinny zostać wkomponowane w hasło, zgodnie z założeniem pozwalającym na pełne wykorzystanie informacji geograficznych, a jednocześnie na uchwycenie miejsca danego leksemu w strukturze gwarowej regionu z wszechstronną wizualizacją desygnatu.
\end{abstract}

Słowa kluczowe: hasło słownikowe, gwara, słownik gwarowy, mapa, ilustracja, kontekst, kwalifikatory.

\begin{abstract}
The structure of a dialect dictionary entry - a methodological problem of contemporary dialectology. The issue under discussion concerns the methodological issues pertaining to the cognitive and scientific values of an entry in a dialect dictionary, viewed from the point of view of practical usefulness of dialectal, regional and local dictionaries and their practicality in a dialogue between generations and in the region's promotion. The essence of the dictionary entry is the number and arrangement of its components, their representativeness and ability to exert influence; the dictionary contains also maps and illustrations, until recently reserved for other kinds of publications. In general, maps and illustrations should be part of an entry, providing geographic information, allowing at the same time to locate a lexeme in a region's dialect structure and to arrive at its multifaceted visualisations. Keeping in mind its practicality, an entry should be provided with contextual information, using standardised and uniform spelling; it should also include the phonetic, morphological and syntactic peculiarities of a regional dialect. The qualifiers should point to the socially-determined status of a lexeme and form the basis for an entry's interpretation in its chronological, social, cultural and civilisation-related dimensions.
\end{abstract}

Keywords: dictionary entry, dialect, dialect dictionary, map, illustration, context, qualifiers.

Opracowanie materiału dialektalnego łączy się ściśle z metodami i sposobami jego gromadzenia oraz zakresem i stopniem precyzyjności zamieszczonych informacji. W te założenia metodologiczne i koncepcje badawcze wpisują się słowniki gwarowe jako leksykograficzne wykładniki sposobu prezentacji i interpretacji słownictwa gwarowego ${ }^{1}$.

1 (H) Praca realizowana w ramach Programu Ministra Nauki i Szkolnictwa Wyższego pod nazwą „Narodowy Program Rozwoju Humanistyki” w latach 2018-2023 nr projektu 0125/NPRH7/H11/86/2018. 
Ukazaniu się Słownika gwar polskich Jana Karłowicza (1900-1911), poprzedzonego zbiorami słownictwa w „Pracach Filologicznych” (m. in.: Gloger 1983, 795-904; Łopaciński 1899, 681-976), a następnie już w II połowie XX wieku kolejnych opracowań, grupujących materiał gwarowy z całego polskiego obszaru gwarowego (SGP; MSGP), jak i przedstawiających zróżnicowanie wewnątrzdialektalne i międzydialektalne poszczególnych regionów (Dejna 1974-1985; Przymuszała 2013; SGM; SGOWM; SGŚ; Sychta 1967-1973; 1980-1985), mniejszych terytoriów wewnątrz dialektu (Bąk 1960; Cygan 2009; 2018; Górnowicz 1973-1974; Jelonek 2018; Karaś 2020; Kąś 2011; 2015-2019; Kucała 1957; Kutyła 2016; Maciejewski 1969; Maryniakowa, Rembiszewska, Siatkowski 2014; Pelcowa 2012-2020; SGiKK; SGŚC; Steffen 1984; Szewczyk 2014), a także opisujących gwarę jednej wsi (Brzeziński 1982-2009; Pluta 1973; Rak 2005; Szymczak 1965-1973; Zaręba 1954; 1960), zawsze towarzyszyło pytanie o formę językową, strukturę hasła, przydatność zamieszczanych treści i wymiar terytorialny tego typu opracowań. To pytanie jest ciągle powtarzane, ze wskazaniem na nowe aspekty metodologiczne (por. m.in.: Nitsch 1957, 135-139; Karaś 2011; Grabka 2016, 39-51; Kąś 2003, 241-248; Okoniowa 2006, 11-19; Pelcowa 2010, 181-194; 2016, 251-259; Reichan 1990, 135-142; 2000, 7-16; 2010, 215-225; Sierociuk 2010, 135-143; Żmigrodzki 2008), wpisane w zmieniającą się rzeczywistość wiejską, a także w nurt badań etnolingwistycznych i kulturoznawczych (SSiSL; Kąś 2011; 2015-2019; Jelonek 2018; Pelcowa 2012-2020; Przymuszała 2013; Przymuszała, Świtała-Trybek 2021).

Aby jednak w pełni przekazać aspekt interpretacyjny gwarowych opracowań leksykalnych, należy zadbać nie tylko o zawartość treściową, z informacjami istotnymi i koniecznymi oraz uzupełniającymi, ale też podkreślić praktyczny aspekt hasła słownikowego, wzmocniony ikonografią, pozwalającą lepiej zrozumieć i zinterpretować dawne słowa i desygnaty. Należy przy tym zastanowić się nad układem haseł w słowniku: alfabetyczny (np.: SGP; MSGP; SGM; Kąś 2015-2019; Przymuszała 2013) czy tematyczny (np.: Anusiewicz, Skawiński 1996; Kucała 1957; Pelcowa 2012-2020; Piotrowicz 2004; SSiSL). Obie formy prezentacji materiału są stosowane w polskiej praktyce leksykograficznej.

Hasło słownikowe - jak zgodnie stwierdzają autorzy i redaktorzy słowników gwarowych (por. m.in.: Karłowicz 1900-1911; Kucała 1957; Bąk 1960; Górnowicz 19731974; Kąś 2011; 2015-2019; Pelcowa 2012-2020; Pluta 1973; SGP; MSGP; SGM; SGŚ; Rieger, Masojć, Rutkowska 2006; Sychta 1967-1973; Zaręba 1960) - powinno podawać, obok zamieszczonego znaczenia wyrazu, informacji o jego odmianach fonetycznych i specyfikacji morfologicznej, o synonimach i heteronimach oraz (w postaci kwalifikatorów) o społecznym statusie danego leksemu, także geografię wyrazu i konteksty jego występowania z przywołaniem fragmentów wypowiedzi mieszkańców wsi. W miarę potrzeby należy je uzupełniać o inne elementy, np. fotografię lub rysunek desygnatu (Falińska 1974; Kucała 1957: Kąś 2011; 2015-2019; Maciejewski 1969; Maryniakowa, Rembiszewska, Siatkowski 2014; Pelcowa 2012-2020; Pelcowa, Gumowska-Grochot, Skórska 2020; SJMZŁ; SJMPK-Gospodyni; SJMPK-Gospodarz; SJMOG; SGBG; Przymuszała, Świtała-Trybek 2020; SSiSL II, z. 3 i 4; Szewczyk 2014; Jelonek 2018), mapę językową (Pelcowa 2012-2021: Pelcowa, Gumowska-Grochot, Skórska 2020); oraz informacje etymologiczne (por. SGŚ; SGOWM; Brzeziński 
1982-2009; Górnowicz 1973-1974; Steffen 1984) i etnograficzne (SSiSL; Sychta 1967-1976; 1980-1985; Bąk 1960; Górnowicz 1973-1974; Kąś 2011; 2015-2019; Kucała 1957; Maciejewski 1969; Pelcowa 2012-2020; SGŚC; Zaręba 1954). Szczegółową i wyczerpującą charakterystykę słowników gwarowych dawnych i współczesnych, opublikowanych do roku 2010, z omówieniem systemu odsyłaczy i mikrostruktury leksykonów oraz charakterystyką wybranych słowników naukowych, przedstawiła Halina Karaś w monografii Polska leksykologia gwarowa (Karaś 2011).

W słowniku gwarowym słowo jest znakiem desygnatu, dlatego też nazwa i desygnat stanowią jedność, podlegającą wspólnemu opisowi. Desygnat

wyodrębnia się z rzeczywistości nie jako izolowana rzecz, ale jako element pozostający w określonych związkach z innymi fragmentami tejże rzeczywistości (Doroszewski 1962, 142),

a słowa

są kryształami, które załamują w sobie obraz świata i skupiają jego wybrane aspekty; wiążą się siecią relacji z innymi słowami, z przedmiotami, z człowiekiem, z faktami z historii własnej i historii wspólnoty językowej. Studiowanie zasobu leksykalnego języka oraz znaczeń słów otwiera perspektywę na całą kulturę (Bartmiński 2007, 34).

Wyraźne odniesienie do rzeczywistości pozajęzykowej i ścisłe usytuowanie desygnatu i jego nazwy w określonym kręgu znaczeniowym i kulturowym jest istotną właściwością słownika gwarowego, łączącego definicję leksykograficzną (naukową) z dodatkowymi informacjami przy artykule hasłowym i definicją użytkownika gwary, podaną w przywoływanych fragmentach wypowiedzi mieszkańców wsi. Większość zasobu leksykalnego stanowią słowa dawne, czasem prawie zapomniane, należy zatem pamiętać o bogatej obudowie tych słów w kontekst kulturowy i obyczajowy. Analiza wypowiedzi mieszkańców wsi dostarcza interesującej wiedzy na temat użycia słowa w aspekcie społecznym, kulturowym, obyczajowym. Relacji tej towarzyszy określenie znaczeń wyrazów i zakresu ich użycia, a także wpisanie słowa i opisywanego pojęcia w strukturę językową i kulturową oraz w opozycję przeszłość - współczesność, z uwzględnieniem świadomości językowej, kompetencji językowej i kompetencji komunikacyjnej użytkowników gwary. Ważny jest kontekst, w jakim wyraz występuje oraz jego uwarunkowania społeczne, kulturowe, obyczajowe, a także: Jak wygląda? Do czego służy? Jakie ma zastosowanie? Gdzie występuje? Kiedy jest używany? Kto używa? Jakie przywołuje skojarzenia? Jakie są z tym związane powiedzenia, przepowiednie, przysłowia, legendy? (por. Pelcowa 2003, 299-310; 2012-2020). Taki sposób opisu łączy walor dokumentu $\mathrm{z}$ interpretacją i kreacją dialektologiczno-etnolingwistyczną materiału, nie tylko rejestruje słownictwo, ale także go interpretuje.

Słownik gwarowy powinien pokazać z jednej strony bogactwo nazw i znaczeń, z drugiej uchwycić i pokazać dynamikę zmian. Powinien uwypuklić to, co charakterystyczne i typowe dla danego obszaru, osobliwości leksykalne, nazwy sporadyczne i jednostkowe, a więc - jak twierdzi Jerzy Reichan $(2000,13)$ - to, co indywidualne na tle systemu panującego $\mathrm{w}$ danej gwarze, a wiedza jednostkowa powinna łączyć się 
z wiedzą ogólną. Należy przy tym pamiętać, że większość mieszkańców wsi używa zamiennie wyrazów gwarowych i ogólnopolskich, dlatego słowniki nie mogą mieć charakteru wyłącznie dyferencyjnego. Określenie stosunku

materiału gwarowego do ogólnopolskiego i przyjęcie dyferencyjności jako podstawy metodologicznej, ma istotne znaczenie zarówno dla określenia stopnia precyzyjności opisu, jak i dla naświetlenia sytuacji aktu komunikacji. Zakres użycia słów gwarowych i ogólnopolskich zależny jest od tego, kto mówi, do kogo, na jaki temat, w jakiej sytuacji, w jakim miejscu, jakie wykształcenie i miejsce zamieszkania posiadają rozmówcy, jaki krąg kulturowy prezentują, w jakim są wieku i jakiej płci (Pelcowa 2013, 591).

Funkcję interpretatora dodatkowego pełnią w strukturze hasła słownikowego kwalifikatory gwarowe, przyjmujące często postać operatorów metatekstowych (Ożóg 1990; 1997, 129-137), organizujących i modyfikujących tekst gwarowy i wykreowany na jego podstawie obraz. Wpisane w parafrazy ludowe, sytuują wypowiedź w określonym kręgu kulturowym, umieszczają ją w czasie i przestrzeni, odsyłają do przeszłości, wartościują otaczającą rzeczywistość i uwypuklają opozycje, funkcjonujące na zasadzie przeciwstawienia i jednocześnie połączenia tego, co dawne, z tym, co nowe. Jak stwierdza Bogdan Walczak,

pozwalają na odróżnianie w słownictwie wielu jego nacechowań, aspektów, ról i funkcji, usytuowania w czasie, przestrzeni i środowisku, wskazują na frekwencję i procesy wychodzenia z użycia (Walczak 1988, 413),

ale granice oddzielające

zakresy poszczególnych kwalifikatorów nie są ostre, np. ten sam wyraz może, w zależności od kontekstu, nabierać różnych odcieni, które pozwalają umiejscowić informacje w czasie (np. kiedyś, teraz), zlokalizować je w przestrzeni (np. tam, tu, tutaj, na wsi, w mieście), ale też - działając na zasadzie opozycji - oddzielić przeszłość od współczesności, nowoczesność od zacofania, tradycję od jej braku. W takiej sytuacji kwalifikatory chronologiczny i geograficzny łączą się często z kwalifikatorem o charakterze aksjologicznym, a dodatkowym elementem wartościującym wypowiedź jest jej subiektywność i połączone z tym wykładniki emocjonalności (Pelcowa 2006, 108).

Może to być wyrażane użyciem form zdrabniających (np. bielusieńki, matusieńka) i oceniających estetycznie lub środowiskowo (np. ładny, paskudny, śliczny, lepszy, gorszy, to brzydkie słowo, niepoprawne, wsiowe takie, tak ino po wiejsku, dawne, stare, zacofane), połączone z określonym fragmentem rzeczywistości i do niej odnoszone, np. nazwa lepsza - nazwa gorsza, ale też dawna wieś zacofana - współcześnie żyje się lepiej. Podobną rolę pełnią wykładniki modalne, wspomagające wiarygodność wypowiedzi, konkretyzowane przez zaimki i formuły prawdziwościowe (por. Bartmiński 1989, 52-56), przyjmujące postać zdań metatekstowych (np. ono takie niewyraźnie byto, może to ino zwidy; to jest faktycznie prawda; może to było, a może ino bujda; może tak, a może nie, ja nie wiem) lub wyrazów modalnych (np. niby, rzekomo, 
faktycznie, pewnie, musi, chyba, być może, możliwe). Uwypuklają się przy tym różnice pokoleniowe i świadomościowe, z uwzględnieniem swojskości i obcości (Benedyktowicz 2000; Engelking 2007, 67; Masłowska 2007, 109-131; Pelcowa 2007, 86; 2011, 13-26; Tokarski 1999, 80), w których zawiera się z jednej strony zasięg geograficzny, z drugiej pewien rodzaj ksenofobii językowej w myśl zasady, że obcy są gorsi, a więc i gorzej mówią. Istotną rolę odgrywa też kwalifikator sytuacyjny, pokazujący oficjalność, półoficjalność i nieoficjalność wypowiedzi. Ważne są także kwalifikatory: kulturowy, obyczajowy i społeczny, wskazujące na słownictwo tożsame i różne kulturowo, oraz uwydatniające rozwarstwienie społeczne współczesnej wsi.

Kwalifikatory stają się istotnymi wykładnikami interpretacji wyrazu hasłowego i uwarunkowań chronologicznych, społecznych, kulturowych, obyczajowych, sytuacyjnych, cywilizacyjnych nazwy oraz określanego przez nią desygnatu, a także

wpisują się w treść, są jej nierozłącznym elementem, a zatem nie podają wyłącznie informacji dodatkowych, ale są sposobem postrzegania otaczającej rzeczywistości współczesnej i dawnej, a co za tym idzie jednym z językowych mechanizmów jej interpretacji. Użytkownik gwary ma samorefleksję, potrafi interpretować to, o czym mówi i jak mówi, a także ma dystans do tego, co mówi (Pelcowa 2006, 108-109).

Ta refleksja nad językiem zaznacza się zarówno na poziomie tekstu, jak i poza tekstem, i może zostać odzwierciedlona w opracowaniach typu słownikowego przez odpowiednie sygnowanie poszczególnych form, wplatanie ich w kontekst, a także sytuowanie chronologiczne w czasie i w przestrzeni.

Hasło słownikowe powinno emanować nie tylko słowem, ale też obrazem (fotografia, rycina, mapa, znaki specjalne).

Jest to szczególnie istotne przede wszystkim wtedy, gdy przedmiotem rozważań są desygnaty dawne [...], już zanikłe i nieznane, często zapomniane. Obraz je odświeża i wraca do życia, słowo konkretyzuje przekaz dawny. Zespolenie obu elementów w całość służy lepszemu zrozumieniu przeszłości [...], łącząc to, co dawne, z tym, co współczesne (Pelcowa 2015, 229-230).

Połączenie obu elementów i wpisanie ich w strukturę hasła pozwala, jak pisał Witold Doroszewski (1962, 136-146; SJP XXVII), na osadzenie nazwy i desygnatu w przestrzeni nie tylko językowo-kulturowej, ale społecznej, obyczajowej, środowiskowej i cywilizacyjnej. W słowniku gwarowym obraz jest dopełnieniem i uzupełnieniem tekstu, nie tylko ozdobnikiem, służy do werbalnego opisu i uporządkowania świata, dając tym samym możliwość dodatkowego dointerpretowania tego, czego nie da się wyrazić w sposób dla wszystkich zrozumiały (szczególnie dla ludzi młodego pokolenia) tylko słowami. Staje się formą definicji, uzupełniającej tekst pisany i w sposób jednoznaczny włączającej go w opisywaną rzeczywistość, dlatego też ma w definiowanym haśle ściśle określoną pozycję i ściśle określone miejsce.

Tekst i obraz to, we współcześnie opracowywanych słownikach gwarowych, dwa równorzędne elementy organizacji przestrzeni słownikowej (por.: Kąś 2011; 20152019; Pelcowa 2012-2020) lub uzupełnienie hasła słownikowego o treści etnograficzne 
i kulturowe. Ilustracja jest bezpośrednio wkomponowana $\mathrm{w}$ hasło $\mathrm{w}$ postaci czarno -białego rysunku (Falińska 1974; Kucała 1957; SGŚC; Zaręba 1954) lub kolorowej fotografii (Pelcowa 2012-2020, I-IV; SJMZŁ; SJMPK-Gospodyni; SJMPK-Gospodarz; SJMOG; SGBG), dodana na końcu słownika w postaci kolorowej wkładki ze zdjęciami desygnatów (Kąś 2011; 2015-2019; Pelcowa 2012-2020 V-VII; Pelcowa, Gumowska-Grochot, Skórska 2020; Przymuszała, Świtała-Trybek 2021; SSiSL II, z. 3 i 4; Szewczyk 2014) lub wkładki z czarno-białymi rysunkami (Maryniakowa, Rembiszewska, Siatkowski 2014; Jelonek 2018).

Mówiąc o relacji zachodzącej między zapisem mowy a dołączonym do niego obrazem, należy też zwrócić uwagę na znaki specjalne jako formę graficznej organizacji przestrzeni słownikowej w dotychczasowej praktyce leksykograficznej. Nie jest to jednak traktowanie zapisu słów jak obrazów, ale sposób wykorzystania znaków dodatkowych, funkcjonujących obok kwalifikatorów, wyposażonych w sens i odsyłających do rzeczywistości tekstowej. Znaki specjalne pełnią w słownikach nie tylko funkcję wizualizacji hasła, ale wskazują też na jego uwarunkowania treściowe na poziomie tekstu. Taką rolę odgrywają m.in. symbole znaków w Stowniku stereotypów i symboli ludowych (SSiSL), Słowniku gwar Ostródzkiego, Warmii i Mazur (SGOWM), Stowniku gwar kaszubskich (Sychta 1967-1973), Słowniku gwar ślaskich (SGŚ)².

Umieszczanie w przestrzeni leksykograficznej słów i obrazów jako kompatybilnych elementów organizacji przestrzeni językowej, powoduje wyrównanie dysproporcji między obecnością elementów werbalnych i wizualnych, a tym samym nie tylko uatrakcyjnia hasło słownikowe i podnosi jego estetykę, ale zaopatruje je w dodatkowe walory interpretacyjne. Często mamy bowiem do czynienia, szczególnie w sferze ludowej kultury materialnej, z zanikiem opisywanego desygnatu czy pojęcia, jego zejściem ,do podziemia" w zakresie nazywania i umiejętności interpretowania określonego fragmentu rzeczywistości, np. dawnych sprzętów domowych, naczyń, potraw, chwastów, ziół, narzędzi rolniczych i ich części. Słownik, szczególnie regionalny (a takich ostatnio wychodzi dużo - por. m.in.: Cygan 2018; Kąś 2011; 2015-2019; Pelcowa 2012-2020; SGiKK; SGM; SGOWM; SGŚ), obok przydatności ściśle naukowej, leksykograficznej, ma także pełnić funkcję promocyjną i dydaktyczną. Wyjątkową rolę należy w tym zakresie przypisać nowej kategorii słownika lokalnego i regionalnego, tworzonego przy współudziale mieszkańców wsi w poznańskim środowisku dialektologicznym. Są to opracowania tworzone pod redakcją naukową Jerzego Sierociuka, Błażeja Osowskiego i Justyny Kobus (SJMZŁ; SJMPK-Gospodyni; SJMPK-Gospodarz; SJMOG; SGBG).

Szczególnym rodzajem obrazu jest mapa językowa, która w polskiej praktyce dialektologicznej do tej pory była wykorzystywana przede wszystkim w atlasach i monografiach. W słownikach geografia wyrazu była sygnowana przez umieszczenie nazw miejscowości i regionów oraz odwołanie do źródeł drukowanych (Karłowicz 19001911; Dejna 1974-1985; SGP; MSGP; SGM; SGŚ). Ale - co można zaobserwować już po wycinkowej prezentacji w słownikach (por. m.in.: Pelcowa 2012-2020) - mapa stanowiąca integralną część hasła słownikowego i wkomponowana w hasło, pozwala na pełniejsze wykorzystanie informacji geograficznych, a jednocześnie na uchwycenie miejsca danego leksemu w strukturze gwarowej regionu. Jest nie tylko ekspozycją

\footnotetext{
2 Szersze rozwinięcie tego wątku, uzupełnione przykładami, por. Pelcowa 2015, 227-241.
} 
materiału, ale także jego interpretacją oraz wizualnym przeniesieniem i konkretyzacją opisywanej przestrzeni. Pozwala tę przestrzeń lepiej przyswoić i jednocześnie uatrakcyjnić hasło. Wskazuje też na dwa elementy, ważne z punktu widzenia leksyki gwarowej: aspekt czasu i przestrzeni jako z jednej strony istotne wykładniki geografii lingwistycznej będącej metodą badawczą, z drugiej - jako wyraźne określenie charakteru nazwy (konkretyzowane w haśle dodatkowo przez kwalifikatory) i jej miejsca w przestrzeni geograficznej regionu. Wykorzystanie metody geografii lingwistycznej spełnia nieocenioną rolę w słownikach gwarowych, dla których - w odróżnieniu od słowników języka ogólnego - zasięg jest podstawowym kryterium dyferencjacji i specyfikacji regionalnej. Zagadnienie kartograficznego przedstawienia materiału jest bowiem nie tylko sprawą techniczną, ale łączy się ściśle z założeniami metodologicznymi, a głównym celem mapy jako narzędzia badawczego geografii lingwistycznej jest plastyczne przedstawienie na niej układów zjawisk językowych, których wybór i sposób opracowania jest uzależniony przede wszystkim od charakteru samego materiału.

$\mathrm{W}$ tym miejscu pojawia się pytanie o formę mapowania i rodzaj mapy. Barbara Falińska i Anna Kowalska (1993, 346) piszą, że idealnym rozwiązaniem byłby taki słownik, którego materiały mogłyby stać się podstawą zarówno map leksykalnych, jak i semantycznych, z jednoczesnym wykorzystaniem mapy jako dopełnienia i uzupełnienia hasła słownikowego. Badaczki przywołują, jako niemożliwy do zrealizowania, postulat wysunięty przez Antoniego Furdala (1963, 315), a dotyczący opracowania jednolitego sposobu wydawania leksykalnych zbiorów gwarowych, który mógłby połączyć atlas i słownik gwarowy (Falińska, Kowalska 1993, 346-347; 2003, 105-107). To założenie jest obecnie realizowane, a najnowsze osiągnięcia leksykografii gwarowej pozwalają łączyć metody opracowań atlasowych i słownikowych, z pełnym wykorzystaniem mapowania w słowniku gwarowym. Dzięki temu współczesne słowniki stają się nie tylko zbiorem słów dawnych, ale interpretacją języka i kultury ludowej jako całości.

Mapy językowe nie sprawdzają się jednak we wszystkich rodzajach leksykonów gwarowych. W przypadku dużego zróżnicowania geograficznego regionu, różnorodnego kulturowo, pogranicznego, niejednorodnego etnicznie, np. w Stowniku gwar Lubelszczyzny (Pelcowa 2012-2020) mapa spełnia istotną rolę wizualnej specyfikacji geograficznej. Daje czytelnikowi lepszą orientację w usytuowaniu przestrzennym danej nazwy, zasięgu jej występowania (zwarcie, wyspowo, w rozproszeniu, sporadycznie, nierównomiernie, centralnie czy peryferyjnie), naświetla związki leksykalne danego obszaru z obszarami sąsiadującymi. Każda z tych informacji niesie pewne treści rzutujące na charakter nazwy i określanego przez nią desygnatu. Dowiadujemy się ponadto o usytuowaniu nazwy wśród innych określeń danego desygnatu - synonimów i heteronimów - oraz o jej ekspansywnym lub recesywnym charakterze, na który wskazuje zasięg i miejsce lokalizacji. Przy większych obszarach gwarowych, np. całego terytorium kraju czy dialektu, wykorzystanie mapy jest utrudnione, pojawiają się problemy techniczne związane z brakiem przejrzystości obrazu, a w słownikach lokalnych nie ma potrzeby pokazywania specyfikacji geograficznej $\mathrm{w}$ formie mapowania.

Słownik gwarowy, pozostając w zgodzie z tradycją i jednocześnie wypełniając przesłania cywilizacyjne współczesnego świata, powinien łączyć sferę językową i kulturową, zawierać ilustrację desygnatu, szczegółową geografię słowa (w miarę możliwości 
z mapą językową) oraz obszerne konteksty wpisujące leksem i desygnat w szeroko pojętą rzeczywistość dawną i współczesną, z dużym naciskiem na wypowiedzi użytkowników gwary jako swoiste identyfikatory otaczającego świata realnego i mentalnego. Hasło słownikowe powinno być przejrzyste i zrozumiałe zarówno dla językoznawców, jak i dla niespecjalistów - osób spoza kręgu dialektologii i językoznawstwa.

Wskazane sposoby konstruowania hasła i metody opisu materiału w opracowaniach gwarowych są niezbędne, aby słowniki mogły sprostać wymogom współczesnych czasów i wypełnić stojące przed nimi zadania - z jednej strony zachować gwarę, pokazać bogactwo nazw i znaczeń, uwypuklić to, co charakterystyczne i typowe dla danego obszaru, wskazać na osobliwości leksykalne, nazwy sporadyczne i jednostkowe, z drugiej uchwycić i pokazać dynamikę zmian językowych, uwarunkowanych przemianami cywilizacyjnymi. Budowanie słownika złożonego z kilkuset czy nawet kilku tysięcy wyrazów, ale poprzestającego tylko na objaśnieniu ich znaczeń, jest w takiej sytuacji daleko idącym nieporozumieniem, gdyż będzie wyłącznie zbiorem słów dawnych - co jest ważne i potrzebne - ale nie wypełni wystarczająco ani funkcji komunikatywnej, ani poznawczej, a tym bardziej edukacyjnej czy promocyjnej.

Zmieniła się otaczająca rzeczywistość, która wyeliminowała z codzienności wiele desygnatów i ich nazwy, w związku z tym słownik gwarowy ma przybliżyć przeszłość jako wartość autoteliczną, dziedzictwo językowe miejsca, regionu i ustępującego czasu. Młodzi ludzie to „pokolenie obrazkowe”, do którego bardziej przemawia ilustracja niż tekst, i ten fakt stwarza potrzebę zastanowienia się nad funkcjonowaniem słownika przekazującego treści w formie pisma i obrazu, a tym samym sfery opisu, prezentacji, ujęcia świata i dotarcia do społeczeństwa, coraz bardziej zmieniającego się cywilizacyjnie i mentalnościowo.

\section{Literatura}

Anusiewicz J., Skawiński J. (1996), Stownik polszczyzny potocznej, Warszawa-Wrocław.

Bartmiński J. (1989), Językowe sposoby porządkowania świata. Uwagi na marginesie biłgorajskich relacji o kosmosie, „Etnolingwistyka”, t. 2, s. 49-58.

Bartmiński J. (2007), Czym zajmuje się etnolingwistyka?, [w:] J. Bartmiński, Stereotypy mieszkaja w języku. Studia etnolingwistyczne, Lublin, s. 32-39.

Bąk P. (1960), Stownictwo okolic Kramska na tle kultury ludowej, Wrocław.

Benedyktowicz Z. (2000), Portrety ,obcego”. Od stereotypu do symbolu, Kraków.

Brzeziński W. (1982-2009), Słownictwo krajniackie. Stownik gwary wsi Podróżna w Zlotowskiem, t. I-VI, Wrocław.

Cygan S. (2009), Z gwary świętokrzyskiej. Świat dawnej wsi w relacjach mieszkańców. Pogwarki. Twórczość ludowa. Stowniczek, Kielce.

Cygan S. (2018), Słownik gwary opoczyńskiej, Opoczno.

Dejna K. (1974-1985), Stownictwo ludowe z terenu byłych województw kieleckiego i łódzkiego, Łódź.

Doroszewski W. (1962), Uwagi o semantyce (Z dyskusji logiczno-lingwistycznej), [w:] W. Doroszewski, Studia i szkice językoznawcze, Warszawa, s. 136-146. 
Engelking A. (2007), Uwagi o mało znanych aspektach kategorii swój/obcy w ujęciu Józefa Obrębskiego, „Etnolingwistyka', t. 19, s. 61-73.

Falińska B. (1974), Polskie słownictwo tkackie na tle słowiańskim. Stownik polskich gwarowych nazw tkackich, Wrocław-Warszawa-Kraków-Gdańsk.

Falińska B., Kowalska A. (1993), O definiowaniu nazw w słownikach $i$ atlasach gwarowych, [w:] O definicjach i definiowaniu, red. J. Bartmiński, R. Tokarski, Lublin, s. 339-348.

Falińska B., Kowalska A. (2003), Stownictwo gwarowe $w$ atlasach i słownikach (rozważania metodologiczne), [w:] Gwary Dziś, t. 2. Regionalne stowniki i atlasy gwarowe, red. J. Sierociuk, Poznań, s. 103-107.

Furdal A. (1963), Kilka uwag o wzajemnych stosunkach stowników i atlasów gwarowych, Wrocław.

Gloger Z. (1893), Stownik gwary ludowej w Tykocińskim, „Prace Filologiczne”, t. IV, s. 795-904.

Górnowicz H. (1973-1974), Dialekt malborski, t. II: Słownik, cz. I-II, Gdańsk.

Grabka B. (2016), Stownik ogólnogwarowy - problemy i wyzwania (na przyktadzie Stownika gwar polskich PAN), [w:] Stowiańskie stowniki gwarowe - tradycja i nowatorstwo, red. D. K. Rembiszewska, Warszawa-Lomża, s. 39-51.

Jelonek T. (2018), Słownik mikrotoponimów gminy Wręczyca Wielka, Kraków.

Karaś H. (2011), Polska leksykografia gwarowa, Warszawa.

Karaś H. (2020), Gwara Bugaja na Pogórzu, Warszawa.

Karłowicz J. (1900-1911), Słownik gwar polskich, t. I-VI, Kraków.

Kąś J. (2003), Etnografia w Stowniku gwarowym, [w:] Gwary Dziś, t. 2. Regionalne stowniki $i$ atlasy gwarowe, red. J. Sierociuk, Poznań, s. 241-248.

Kąś J. (2011), Słownik gwary orawskiej, t. I-II, wyd. 2., Kraków.

Kąś J. (2015-2019), Ilustrowany leksykon gwary i kultury podhalańskiej, t. I-XII, Bukowina Tatrzańska-Kraków-Nowy Sącz.

Kucała M. (1957), Porównawczy stownik trzech wsi małopolskich (Więciórka, Sidzina, Facimiech), Wrocław.

Kutyła J. (2016), Słownik gwary lasowiackiej Kamienia i okolicy na Rzeszowszczyźnie, Rzeszów.

Łopaciński H. (1899), Przyczynki do nowego słownika języka polskiego (słownik wyrazów ludowych z Lubelskiego, mniej z innych okolic Królestwa Polskiego, zrzadka Z Galicyi, Szląska, Prus i Poznańskiego), cz. II, „Prace Filologiczne”, t. V, s. 681-976.

Maciejewski J. (1969), Stownik chetmińsko-dobrzyński (Siemoń, Dulsk), Toruń.

Maryniakowa I., Rembiszewska D., Siatkowski J. (2014), Różnojęzyczne słownictwo gwarowe Podlasia, Suwalszczyzny i pótnocno-wschodniego Mazowsza, Warszawa.

Masłowska E. (2007), Swoi i obcy przy wspólnym stole, „Etnolingwistyka’, t. 19, s. 109-131.

MSGP, Mały słownik gwar polskich, oprac. zesp. R. Kucharzyk, A. Niezabitowska, J. Reichan, M. Tokarz, W. Wójcicka, J. Wronicz, red. J. Wronicz, Kraków 2010.

Nitsch K. (1957), Zagadnienia ogólnopolskiego stownika gwarowego, „Nauka Polska”, R. 5, nr 1, s. 135-139.

Okoniowa J. (2006), Stan obecny i perspektywy ogólnopolskiego stownika gwarowego, Studia Dialektologiczne, t. III, red. J. Okoniowa, Kraków, s 11-19.

Ożóg K. (1990), Leksykon metatekstowy wspótczesnej polszczyzny mówionej. Wybrane zagadnienia, Kraków. 
Ożóg K. (1997), Operatory metatekstowe w polszczyźnie potocznej, [w:] Z polszczyzny historycznej $i$ wspótczesnej, red. T. Ampel, Rzeszów, s. 129-137.

Pelcowa H. (2003) Definicja w świadomości językowej ludności wiejskiej, [w:] Stowa jak mosty nad wiekami, Księga jubileuszowa dedykowana Prof. dr hab. Barbarze Falińskiej, red. U. Sokólska, P. Wróblewski, Białystok, s. 299-310.

Pelcowa H. (2006), Kwalifikatory w wypowiedziach gwarowych jako sposób interpretacji świata, „Poznańskie Spotkania Językoznawcze”, t. XV, s. 107-116.

Pelcowa H. (2007), Swój / obcy w świadomości mieszkańców lubelskich wsi, „Etnolingwistyka’, t. 19 , s. $75-87$.

Pelcowa H. (2010), Stownik gwar Lubelszczyzny - stan i perspektywy prac leksykograficznych, „Rozprawy Komisji Językowej Łódzkiego Towarzystwa Naukowego”, t. LV, s. 181-194.

Pelcowa H. (2011), Swój - obcy w językowej przestrzeni miasta ali wsi, [w:] Miasto, t. 3: Przestrzeń zróżnicowana językowo, kulturowo i społecznie, red. M. Święcicka, Bydgoszcz, s. $13-26$.

Pelcowa H. (2012-2020), Słownik gwar Lubelszczyzny, t. I: Rolnictwo. Narzędzia rolnicze. Prace polowe. Zbiór i obróbka zbóż, 2012; t. II: Rolnictwo. Transport wiejski. Rośliny okopowe i paszowe. Gleby i rodzaje pól. Uprawa lnu i konopi. Zbiór siana, 2014; t. III: Świat zwierzat, 2015; t. IV: Sad i ogród warzywny. Budownictwo i przestrzeń, 2016; t. V: Świat roślin, 2017; t. VI: Pokarmy, 2019, t. VII: Odzież i obuwie. Przędzenie lnu i tkanie płótna, 2020, Lublin.

Pelcowa H. (2013), Stowniki i atlasy gwarowe jako sposób interpretacji słownictwa, [w:] Cum reverentia, gratia, amicitia..., Księga jubileuszowa dedykowana Profesorowi Bogdanowi Walczakowi, t. II, red. J. Migdał, A. Piotrowska-Wojaczyk, Poznań, s. 589-596.

Pelcowa H. (2015), Tekst i obraz w praktyce leksykograficznej (na przykładzie stowników gwarowych), [w:] Działania na tekście. Przekład. Redagowanie. Ilustrowanie, red. S. Niebrzegowska-Bartmińska, M. Nowosad-Bakalarczyk, T. Piekot, Lublin, s. 227-241.

Pelcowa H. (2016), Regionalne stowniki gwarowe w dobie globalizacji, [w:] Dawne z nowym łacząc... In memoriam Mariani Kucała, red. J. Klimek-Grądzka, M. Nowak, Trwałość i Zmienność w Języku, Lublin, s. 251-259.

Pelcowa H., Gumowska-Grochot I., Skórska B. (2020), Stownik gwar Lubelszczyzny, t. VIII: Człowiek i rodzina. Higiena i choroby. Meble, sprzęty i prace domowe, Lublin.

Piotrowicz A. (2004), Stownictwo i frazeologia życia towarzyskiego w polskiej leksykografii XX wieku, Poznań.

Pluta F. (1973), Stownictwo Dzierżysławic w powiecie prudnickim, Wrocław.

Przymuszała L. (2013), Stownik frazeologizmów i typowych połaczeń wyrazowych $w$ gwarach śląskich, Opole.

Przymuszała L., Świtała-Trybek D. (2021), Leksykon dziedzictwa kulinarnego Ślaska, Opole.

Rak M. (2005), Słownik frazeologiczny gwary Dębna w Górach Świętokrzyskich, Kraków.

Reichan J. (1990), Stownictwo gwarowe w przestrzeni i czasie, [w:] Dynamika rozwoju stownictwa, red. J. Reichan, „Studia Linguistica Polono-Slovaca”, t. III, s. 135-142.

Reichan J. (2000), Stownik gwar polskich jako synteza polskiej leksykografii gwarowej, [w:] Stowiańskie stowniki gwarowe, red. H. Popowska-Taborska, Warszawa, s. 7-16.

Reichan J. (2010), Typologia słowników gwarowych na tle ogólnej typologii słowników, Studia Dialektologiczne, t. IV, red. H. Kurek, A. Tyrpa, J. Wronicz, Kraków, s. 215-225.

Rieger J., Masojć I., Rutkowska K. (2006), Stownictwo polszczyzny gwarowej na Litwie, Warszawa. 
SGBG, Z. Dragan, D. Woźna, J.Budz, J. Kowalczyk, E. Łukuś, J. Majerczak (2014), Co wieś, to inna pieśń. Slownik gwary Bukówca Górnego w Wielkopolsce i regionu Spisza w Małopolsce, red. J. Sierociuk, A. Czesak, Kraków.

SGiKK, Stownik gwary i kultury Kujaw, t. I: $A-H$, red. Z. Sawaniewska-Mochowa, Bydgoszcz 2017.

SGM, Słownik gwar małopolskich, t. I-II, oprac. zesp. M. Buława, B. Grabka, E. Grześkiewicz, A. Kostecka-Sadowa, J. Kozioł, R. Kucharzyk, A. Niezabitowska, E. Popławski, M. Tokarz, A. Tyrpa, J. Wronicz, B. Ziajka, red. J. Wronicz, Kraków 2016-2017.

SGOWM, Stownik gwar Ostródzkiego, Warmii i Mazur, t. I-II, red. Z. Stamirowska, 1987-1991; t. III, red. Z. Stamirowska, H. Perzowa, 1993; t. IV-V, red. H. Perzowa, D. Kołodziejczykowa, 2002-2006; t. VI pod kier. A. Tyrpy, red. D. Kołodziejczykowa, K. Sobolewska, 2014; t. VIII, red. K. Sobolewska, 2018; Kraków-Warszawa 1987-2018.

SGP, Stownik gwar polskich, oprac. Zakład Dialektologii Polskiej IJP PAN, kier. M. Karaś (Źródła, z. 1-2), J. Reichan, S. Urbańczyk (z. 3-9), J. Okoniowa, J. Reichan (z. 10-15), J. Okoniowa (z. 16-23), R. Kucharzyk (z. 24-32), Kraków 1977-2019.

SGŚ, Stownik gwar ślaskich, t. I-XVII, red. B. Wyderka, Opole 2000-2020.

SGŚC, Słownik gwarowy Śląska Cieszyńskiego, red. J. Wronicz, wyd. II, Wisła-Ustron 2010.

Sierociuk J. (2010), Założenia metodologiczne regionalnych słowników gwarowych powstających przy wspótudziale środowisk lokalnych, [w:] Studia Dialektologiczne, t. IV, red. H. Kurek, A. Tyrpa, J. Wronicz, Kraków, s. 135-143.

SJMOG, Stownik języka mieszkańców okolic Gniezna. Święta, wierzenia i przesądy, red. J. Kobus, T. Gniazdowski, Poznań 2018.

SJMPK-Gospodarz, Gospodarz. Stownik mieszkańców powiatu kolskiego, red. B. Osowski, Poznań 2018.

SJMPK-Gospodyni, Gospodyni. Stownik mieszkańców powiatu kolskiego, red. B. Osowski, Poznań 2018.

SJMZŁ, Słownik języka mieszkańców ziemi tukowskiej. Praca na roli $i$ w gospodarstwie, red. J. Sierociuk, Poznań 2019.

SJP, Słownik języka polskiego, t. I: A-Ć, red. W. Doroszewski, Warszawa 1958.

SSiSL, Stownik stereotypów i symboli ludowych, t. I: Kosmos, z. 1: Niebo, światta niebieskie, ogień, kamienie, 1996; z. 2: Ziemia, woda, podziemie, 1999; z. 3: Meteorologia, 2012; z. 4: Świat, światto, metal, 2012; t II: Rośliny, z. 1: Zboża, 2017; z. 2: Warzywa, przyprawy, rośliny przemystowe, 2018, z. 3: Kwiaty, 2019; z. 4: Ziola, 2019; z. 5: Drzewa owocowe $i$ iglaste, 2020, red. J. Bartmiński, zast. red. S. Niebrzegowska-Bartmińska, Lublin 19962020 .

Steffen W. (1984), Stownik warmiński, Wrocław.

Sychta B. (1967-1973), Stownik gwar kaszubskich na tle kultury ludowej, t. I-VI, Wrocław.

Sychta B. (1980-1985), Stownictwo Kociewia, t. I-III, Wrocław-Warszawa-Kraków-Gdańsk.

Szewczyk Z.P. (2014), Stownik gwary Lachów Sadeckich (Podegrodzkich), Podegrodzie.

Szymczak M. (1965-1973), Stownik gwary Domaniewka w powiecie tęczyckim, cz. I-VIII, Wrocław.

Tokarski R. (1999), Językowy obraz świata w metaforach potocznych, [w:] Językowy obraz świa$t a$, red. J. Bartmiński, Lublin, s. 66-81. 
Walczak B. (1988), Kwalifikatory w słownikach języka polskiego, [w:] Wokót języka. Rozprawy i studia poświęcone pamięci profesora Mieczysława Szymczaka, Warszawa, s. 413-422.

Zaręba A. (1954), Stownictwo Niepołomic, Wrocław.

Zaręba A. (1960), Stownik Starych Siołkowic w powiecie opolskim, Kraków.

Żmigrodzki P. (2008), Słowo - słownik - rzeczywistość, Kraków. 